\title{
Sustainable Water Management in Tidal Lowland Agriculture: A Research Agenda
}

\author{
Meitry Firdha Tafarini ${ }^{1}$, Muhammad Yazid $^{1 *}$ \\ ${ }^{1}$ Master Program in Agribusiness, Faculty of Agriculture, Sriwijaya University \\ *Corresponding Author's e-mail address: yazid_ppmal@yahoo.com
}

Article history

\begin{tabular}{llll}
\hline Received & Received from reviced & Accepted & Available online \\
07 December 2018 & 26 Desember 2018 & 4 January 2019 & 11 january 2019 \\
\hline
\end{tabular}

\begin{abstract}
Water in tidal lowlands may either lack or excessive. Neither lack nor excessive of water is demanded for crop cultivation. Therefore, water management plays an important role in the development of tidal lowland agriculture through maintaining proper water conditions. Since tidal lowland with certain conditions is considered marginal, its utilization for crop cultivation should maintain its fragile characteristics such that its utilization to support crop production can be sustained. Continuing use of tidal lowlands for crop production, therefore, requires agricultural ecosystem management through the establishment and measurement of sustainability in water management. Sustainable water management in tidal lowlands for crop production should not only consider the physical resources (infrastructures), but also human resource as well as financial resource. This paper proposes three agendas for research on water management as follows: (1) identification of specific local water infrastructure developments, (2) initiation of participatory operation and maintenance of water infrastructures, (3) utilization of self-supporting financial means in water management.
\end{abstract}

Keywords: tidal lowlands, water management, sustainability, cultivation

Abstrak (Indonesian):Ketersediaan air pada lahan pasang surut suatu saat mengalami kekurangan tetapi di saat lain mengalami kelebihan. Kekurangan atau kelebihan air tidak diinginkan dalam budidaya tanaman. Karena itu, pengelolaan air memainkan peran penting dalam pengembangan pertanian pada lahan pasang surut dengan mengatur kondisi air yang tepat. Karena lahan pasang surut pada kondisi tertentu dianggap marjinal, maka budidaya tanaman harus memperhatikan sifat rapuh lahan sehingga pemanfaatannya untuk tanaman pangan dapat dipertahankan. Penggunaan lahan pasang surut yang terus-menerus untuk produksi pangan memerlukan pengelolaan ekosistem pertanian melalui pengukuran keberlanjutan pengelolaan air. Karena itu, pengelolaan air yang berkelanjutan di lahan pasang surut untuk produksi pangan seharusnya tidak hanya mempertimbangkan sumberdaya fisik (infrastruktur), tetapi juga sumberdaya manusia dan sumberdaya keuangan. Tulisan ini membahas tiga agenda penelitian pengelolaan air sebagai berikut: (1) pengembangan infrastruktur air spesifik lokasi, (2) inisiasi operasi dan pemeliharaan infrastruktur air partisipatif, (3) kemandirian dalam pendanaan pengelolaan air.

Katakunci: lahan pasang surut, pengelolaan air, keberlanjutan

\section{Introduction}

Unsustainable use of water by human beings has caused water shortage and damage to water resources. In addition, improper water management has caused water shortage to supply various needs. Therefore, sustainability of water management becomes a main issue. The lack of understanding on sustainable water management may have extreme impact. One of these is the farmers' belief that sustainability means inundating rice fields with certain water depths throughout the season [1]. In the theory of sustainable development, there are three issues that must be considered, that is economic, social, and environmental issues. These three pillars must be implemented in an integrated manner [2].

Tidal lowlands is one of the wetland ecosystems. According to the Ramsar Convention, wetlands includes water bodies, river waters, swamps, lakes, river embankments, beaches, bays, rice fields, reservoirs, and irrigation [3]. Each type of wetlands has the characteristics and potential as resource for agriculture. Tidal lowlands as resource for cultivation has the potential life support to provide food (staple food, vegetables, fruits), fiber, boards (wood trees), and bio-pharmacy (medicinal plants). For long time, swamp community have developed a variety of cultivated crops, especially food crops such as rice and maize [3].

In order to utilize tidal lowlands for above benefits, water management is a must. Water management literature proposes three levels of water management system: macro, micro, and on-farm water management [4]. All is related to each other such that water management in a large area can be carried out. Accordingly, its development and maintenance must be carried out collectively.

In South Sumatra, tidal lowlands has been utilized for crop production by the government since 1969 through transmigration program [5]. In the beginning, 
the water system of reclamation was an open network system with the main function for drainage. Since water management arrangements still depend on natural conditions, water management services were considerably limited. In an open network systems, the type of tidal overflow is a major consideration in the implementation of farming systems. With the construction of water control infrastructures, several technical issues in developing tidal lowland agriculture have initially been solved.

Maintaining sustainability of tidal lowlands as natural resources is one of the Sustainable Development Goals (SDGs). The purposes to achieve in 2030 are ensuring sustainable food production systems, implementing good agricultural practices that can increase the productivity and production, maintaining ecosystem health, strengthening adaptive capacity to climate change, extreme weather, drought, floods and other disasters, and improving land and soil quality progressively. Among these, improving water quality by reducing pollution may eliminate the waste and minimize the disposal of chemical and harmful materials which can damage the quality of water [5].

Tidal lowlands development experienced many problems which include water fluctuations, diverse physical and chemical conditions, high soil acidity and organic acids on peat lands, the presence of toxic substances, saltwater intrusion and low fertility. Toxic elements solubility reach the peak in the early weeks of rainy season causing very low $\mathrm{pH}$ and gradually decrease until approaching the dry season. Salinity in tidal lowlands is caused by the presence of seawater which usually occurs in July to September [6]. In root areas, high salinity inhibits the roots in absorbing water and nutrients, even at high concentrations. Especially in acid sulfate soils that have high level of soil and water acidity containing high $\mathrm{Al}, \mathrm{Fe}$ and $\mathrm{H}_{2} \mathrm{~S}$, but nutrient contents such as $\mathrm{P}$ and $\mathrm{K}$ are low [7].

According to Badan Pusat Statistik of South Sumatra Province, at the beginning the utilization of tidal lowland was about to $271,413 \mathrm{Ha}$, currently slightly decreased to $266,674 \mathrm{Ha}$ [8]. Unutilized tidal lowlands would negatively affect water management. Therefore, it is necessary to investigate the appropriate sustainability measures in tidal lowland water management. Sustainability may be investigated through three aspects, which are ecology, social, and economics.

The objective of this paper is to examine the sustainability of water management in tidal lowlands with regards to the achievement of Sustainable Development Goals (SDGs) through a review of relevant literature. This paper is expected to yield a measure of sustainable water management in tidal lowlands to contribute to the achievement of Sustainable Development Goals (SDGs).

\section{Method}

This paper was written through a review of relevant literature in water management development in tidal lowlands from both theoretical and methodological perspectives. The literature reviewed included journals, Sustainable Development Goals (SDGs) documents, reports, etc.

\section{Results and Discussion}

\subsection{Sustainable Development Goals (SDGs)}

Sustainable development is defined as development that can supply today's needs without compromising the ability of future generations to supply their needs. The sustainable development can be achieved if economic components, social inclusions, and environmental protections can be well integrated with each other [14]. Sustainable development in tidal lowlands cannot be separated from its water management system. By developing local specific water infrastructures, initiating participatory operations and maintenance of water infrastructures and the utilization of self-supporting financial means in water management, the sustainability goals will be achieved.

The objectives of Sustainable Development Goals [14] discussed in this paper are the 6th goal, namely to guarantee and manage clean and sustainable water for all and the 13th goal, namely taking immediate action to help and encourage climate actions. To achieve these goals, the SDGs document contains several targets that must be achieved by 2030 , which are:

Goal \#6:

1. Achieving universal and fair access to safe and affordable drinking water for all.

2. Achieving access to proper and fair sanitation and hygiene for all and ending open defecation by paying special attention to the needs of women and girls and those in vulnerable situations.

3. Improving water quality by reducing pollution, eliminating waste disposal and minimizing the disposal of chemicals and harmful materials, halving the proportion of untreated waste water and substantially increasing global safe recycling and reuse.

4. Substantively increasing water use efficiency in all sectors and ensuring sustainable water supply to overcome water scarcity and substantially reduce the number of people experiencing water scarcity.

5. Implementing integrated water source management at every level, including through appropriate collaboration between boundaries.

6. Protecting and improving water-related ecosystems, including mountains, forests, swamps, rivers, water catchments, and lakes.

7. Increasing international cooperation and capacity building support to developing countries in activities and programs related to water and sanitation, including water harvesting, desalination, 
water efficiency, waste water treatment, recycle and reuse technology.

8. Supporting and strengthening the participation of local communities in improving water and sanitation management.

Goal \#13:

1. Strengthening resilience and adaptability to the adverse effects of climate and natural disasters in each country.

2. Integrating climate change related actions into national policies, strategies, and planning.

3. Improving education, awareness, and mitigation capabilities of climate change, adaptability, reducing impacts also early improving the warning of climate change.

4. Implementing the commitments of developed countries to the UN Convention Framework on Climate Change with the aim of jointly mobilizing funds of $\$ 100$ billion per year starting in 2020 from all sources to help the needs of developing countries in mitigation and transparency programs in implementing the Green Climate Fund as soon as possible.

5. Promoting mechanisms to effectively increase the capacity for planning and management of climate change, especially in underdeveloped countries.

Water is an important component in the management of tidal lowlands, so the goals \# 6 and \# 13 of the SDGs are the proper indicators in order to achieve sustainability in tidal lowlands ecosystem. Water management in tidal lowlands can be part of efforts to mitigate and adapt to climate change. The success of these efforts can contribute to the achievement of the SDGs. The sustainable development can be achieved if economic components, social inclusions, and environmental protections can be well integrated each other [14].

\subsection{Threats to Sustainable Water Management in Tidal Lowlands}

Threats to water management in tidal lowlands include deficiency and damage due to human misuse of water. Threats due to natural impacts can also occur in the dry season. In the dry season, tidal lowlands would experience shortage of water so that it can cause the pyrite contained in the soil to oxidize. In this case, the role of infrastructure is very important for soil washing. The strongest pyrite content is at an average depth of $0-20 \mathrm{~cm}$ below the top layer (topsoil) with soil $\mathrm{pH}$ of 2.5 at a temperature of $35^{\circ} \mathrm{C}$ [15]. Pyrite formed is influenced by several factors, including the high content of organic matter, anaerobic atmosphere, the amount of sufficiency of dissolved sulfate, and dissolved iron levels. The condition of pyrite will be stable and safe if it is under the water layer. That is, the potential for oxidized pyrite will be absent if the water layer is above or inundates the pyrite layer continuously, this is another effort besides washing pyrite and other toxic compounds [16]. At the tidal lowlands area in South Sumatra, there are currently many water infrastructures that have been damaged and are not functioning properly so that repairs or rebuilding are needed. This is certainly a threat to sustainable water management which directly affects agriculture, fishery, and non-agricultural waters uses such as the use of water for households. Dredging that should be carried out every five years is done after seven years. This causes the washing of soil is not optimal, irrigating water on the land is hampered and even some of the land is not watered. If the construction of water management infrastructure is not carried out in accordance with the criteria, the land will have an ecologically bad impact.

Infrastructures that are not managed properly will have a negative impact on sustainability of water management in tidal lowlands. In this case, the role of water user association (WUA) is very important. Periodic maintenance can be carried out by WUA at least once every two years depending on the condition of the building and the canal. While maintenance of the canal is carried out at least every five years [17]. However, the existing WUA does not work as it should. In addition, operation of the water infrastructures is not carried out in a participatory manner. This means that the operation is only carried out when farmers want to start cultivation and when they want to harvest.

If WUA is not functioning properly, it will have a financial impact on the operation and maintenance of water management infrastructure. Farmers who participate less will have less willingness to pay for maintenance. Without WUA payment, the existing infrastructure will be abandoned. If this problem is not addressed, it will also affect the production and cause financial losses. Therefore, the assessment of the sustainability of water management by investigating and assessing ecological, social and economic aspects should be performed (see Figure 1).

\subsection{Development of Specific Local Water Infrastructures}

One of the solutions to developing tidal lowland agriculture is the proper management of land and water system. The development of farming in tidal lowland begins with the development of a macro water system that aims to improve the effectiveness of water regulation/control in order to supply crop water needs and to help washing toxic substances to improve soil quality. 


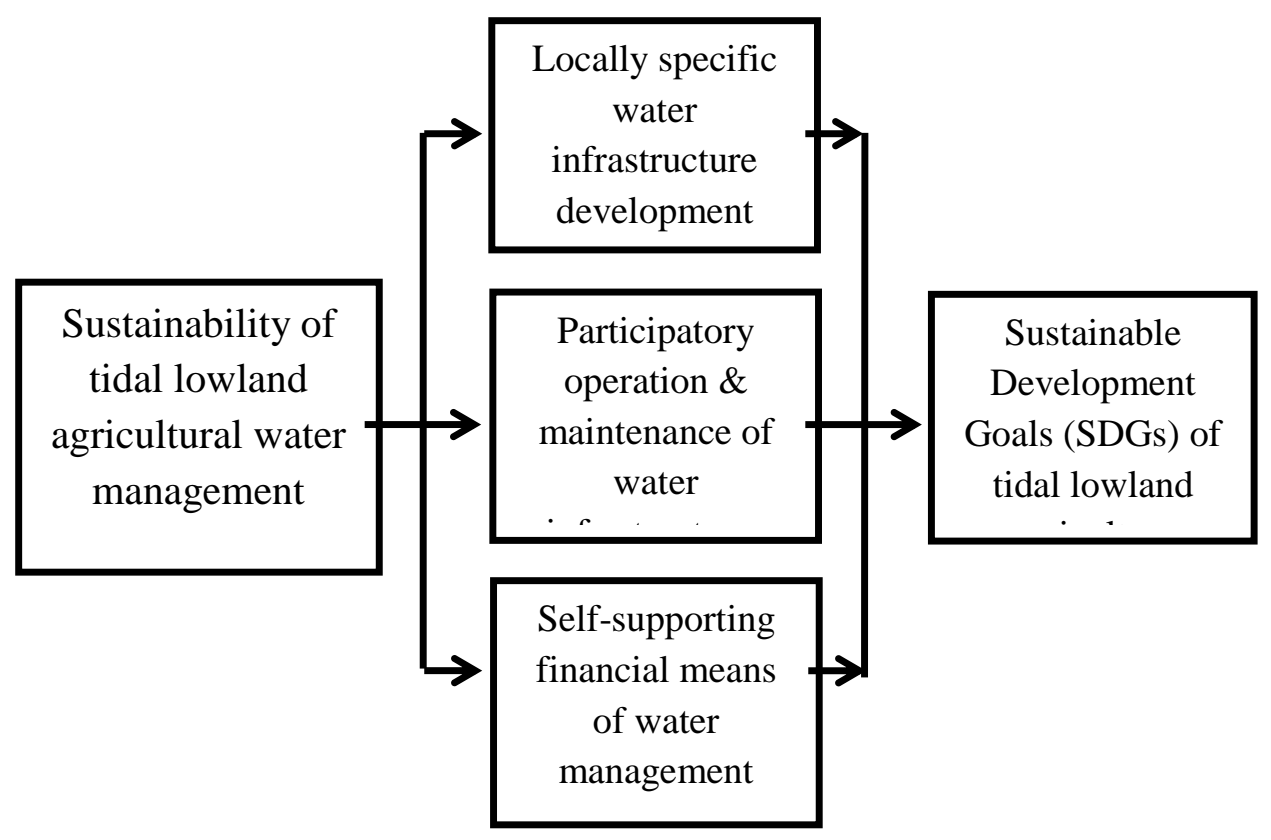

Figure 1. Proposed Research Map

Water management activities include macro and micro water systems. The macro water system covering primary, secondary and tertiary canals is the responsibility of the Directorate General of Water Resource. While the micro-water system at farm level is the responsibility and implemented by farmers, consisting of quarter canals and gates. Water management is done by arranging the water system according to the land hydrotopographic characteristics. In addition, water flow is adapted according to the crop needs [18].

Investment in agricultural development in tidal lowlands is generally partial, so the results are not optimal. The success of the development of tidal lowlands is largely determined by infrastructure support in the form of water systems (canals), buildings (water gate), transportation facilities, and other supports such as markets, schools, hospitals, workshops and others [19]. The micro-water system serves to supply the plant evapotranspiration needs, prevent weed growth in rice cultivation, prevent the formation of toxic materials for plants through flushing and washing, regulating water levels, and maintaining water quality in land and drain plots. Management of micro water systems includes the arrangement and management of water on the quarter canals and land plots according to the plants needs in addition to facilitate the washing of toxic materials. While the water management in tertiary canals aimed to entering the water irrigation, controlling the water level in canals and plots, and regulating the water quality by removing toxic materials formed on the plots and prevent saltwater entry into the land plots [20]. Water management systems at the tertiary and micro levels depend on the type of tidal surge and poisoning rate.
Water management on hydrotopographic A and B needs to be arranged in a one-way flow system, while the hydrotopographic $\mathrm{C}$ and $\mathrm{D}$, the drains need to be blocked with stoplog to keep the water table suitable with the plants needs and allow the rainwater to accommodate in the canals [21].

In Kalimantan, Sumatra, Sulawesi, and Central Kalimantan, there were many water structures (water gates) constructed in the 1980s have been damaged and were not working properly and need to be repaired or rebuilt. Infrastructure developments in tidal lowland are very important. The success of the development of tidal areas is determined by infrastructure support for water management system, building (water gates), transportation, and other supporting facilities [22].

\subsection{Initiation of Participatory Operation and Maintenance of Water Infrastructures}

Operational plans, including planting and water management, are necessary to create the optimal conditions in land use for agriculture and society. Water management plans are translated into procedures of water infrastructures operation [17]. Water management is intended to ensure water availability for crops, drain excess rainwater from farmland, prevent the growth of wild plants (weeds), prevent the toxic substances, prevent the degradation of water quality, and in specific cases prevent the formation of sulfuric acid soils. Implementation of maintenance on a regular basis is absolutely necessary for water management activities to be well organized and reliable. Maintaining includes regular and periodic maintenance [22].

The adoption of technology is carried out so that the operating system on water infrastructure is more 
efficient as well as the management of its human resources. Water user association (WUA) conducts land and water management activities that aimed of operating and maintaining through a participatory approach. WUA also contributes in supporting the planning process, budgeting and implementing of the government water structure requirements. This activity is carried out to solve the problems related to development of technologies and mechanization of agricultural in order to increase crop production through increasing the crop index. Operation and maintenance $(\mathrm{O} \& \mathrm{M})$ is conducted through the empowerment of WUA which aims to improve the responsibility and activities of WUA members [17].

\subsection{Utilization of Self-Supporting Financial Means In Water Management}

Water management in tidal lowlands faces several constraints including lack of capital, labor with less education, low agricultural prices, and weak institutional support for capital provisions. The lack of capital, either to buy farm inputs or to pay wages for farm labor prevent farmers from applying the technologies optimally. To overcome the shortage of capital, farmers usually borrow money from local traders since formal financial institutions such banks and cooperatives are not available in most tidal lowland areas.

Tidal agricultural development should be implemented through agribusiness-oriented business systems. Implementation of development can also be done through coordination and synergistic work among institutions related to the role of farmers and institutional support in the village [18]. The role of WUA should not only be as financial user, but must be directed towards financial independence. In order for water management to be sustainable, water management costs are needed, in addition to the functional water structure and established water management guidelines. These costs are used to carry out operation and maintenance of the system. With financial independence, water management can be carried out properly by WUA to achieve efficient water distribution and to support higher farm productivity [23].

\section{Conclusion}

In order to achieve sustainable water management in tidal lowlands with regard to Goals \#6 and \#13 the research agenda in tidal lowlands water management should include:

1. Investigation on measures of water management means of locally specific water infrastructure development.

2. Assessment of participatory operations \& maintenance of water infrastructure by the WUA.
3. Establishment of measures of self-supporting financial means of water management to achieve sustainability.

\section{Acknowledgement}

The authors wish to thank The Master Program in Agribusiness, Faculty of Agriculture, Sriwijaya University and The Ministry of Research, Technology and Higher Education of The Republic of Indonesia through PMDSU Scholarship Batch III.

\section{References}

[1] M. Suprapto, "Pengelolaan sumberdaya air berkelanjutan dengan tolok ukur operasional indeks kelentingan," J. Gema Tek., vol. 1, no. 1, pp. 133-139, 2007.

[2] A. H. Rahadian, "Strategi pembangunan berkelanjutan," in Prosiding Seminar STIAMI, 2016, vol. 3, no. 1, pp. 46-56.

[3] M. Noor and A. Rahman, "Biodiversitas dan kearifan lokal dalam budidaya tanaman pangan mendukung kedaulatan pangan: kasus di lahan rawa pasang surut," in Prosiding Seminar Nasional Masyarakat Biodiversity Indonesia, 2015, vol. 1, no. 8, pp. 1861-1867.

[4] Departemen Pertanian Indonesia, 5 Tahun Penelitian dan Pengembangan Pertanian 19972001. Jakarta: Badan Penelitian dan Pengembangan Pertanian, 2001.

[5] Ngudiantoro, H. Pawitan, M. Ardiansyah, M. Y. J. Purwanto, and R. H. Susanto, "Modeling of water table fluctuation on tidal lowland area of b/c type: a case in south sumatra," Forum Pascasarj., vol. 33, no. 2, pp. 101-112, 2010.

[6] M. S. Imanudin and S. J. Priatna, "Adaptasi teknologi pengelolaan air untuk budidaya tanaman pangan di lahan rawa sebagai dampak anomali iklim el nino (studi kasus rawa musi ii kota palembang sumatera selatan dan daerah reklamasi rawa kumpeh muara jambi provinsi jambi)," in Prosiding Seminar Nasional Lahan Suboptimal, 2015, pp. 1-10.

[7] Riwandi, Prasetyo, Hasanudin, and I. Cahyadinata, Kesuburan Tanah dan Pemupukan, Edisi I. Bengkulu: Yayasan Sahabat Alam Rafflesia, 2017.

[8] BPS Sumatera Selatan, "Sumsel dalam Angka." Badan Pusat Statistik, Sumatera Selatan, 2015.

[9] D. M. Arsyad, B. B. Saidi, and Enrizal, "Pengembangan inovasi pertanian di lahan rawa pasang surut mendukung kedaulatan pangan," $J$. Pengemb. Inov. Pertan., vol. 7, no. 4, pp. 169 176, 2014.

[10] D. Nazemi, A. Hairani, and Nurita, “Optimalisasi pemanfaatan lahan rawa pasang surut melalui pengelolaan lahan dan komoditas," J. Agrovigor, vol. 5, no. 1, pp. 52-57, 2012. 
[11] Ar-Riza and Alkasuma, "Pertanian lahan rawa pasang surut dan strategi pengembangannya dalam era otonomi daerah," J. Sumberd. Lahan, vol. 2, no. 2, pp. 95-104, 2008.

[12] Subagyo H., "Klasifikasi dan Penyebaran Lahan Rawa," in Karakteristik dan Pengelolaan Lahan Rawa, Indonesia: BBSDLP, 2006, pp. 1-22.

[13] D. A. Suriadikarta, "Teknologi pengelolaan lahan rawa berkelanjutan: studi kasus kawasan ex plg kalimantan tengah," J. Sumberd. Lahan, vol. 6, no. 1, pp. 45-54, 2012.

[14] Outcome SDGs, Dokumen Hasil Tujuan Pembangunan Berkelanjutan. United Nations, 2015, pp. 1-30.

[15] E. F. Yudianto, U. Andawayanti, and T. B. Prayogo, "Penanganan kebutuhan air dan keracunan pirit di daerah irigasi rawa kecamatan jejangkit kabupaten barito kuala dengan mempergunakan model duflow," J. Tek. Pengair., vol. 8, no. 1, pp. 89-99, 2017.

[16] Sustiyah, Y. Sulistiyanto, and F. F. Adji, "Peningkatan pengetahuan petani tentang bahaya pirit (FeS2) dan upaya penanggulangannya pada usaha pertanian pasang surut di daerah mentaren kalimantan tengah," J. Jur. Budid. Pertan. Univ. Palangkaraya, vol. 12, no. 1, pp. 1-7, 2011.

[17] Menteri Pekerjaan Umum Republik Indonesia, Peraturan Menteri Pekerjaan Umum Tentang Pedoman Operasi dan Pemeliharaan Jaringan Reklamasi Rawa Pasang Surut. Republik Indonesia, 2010, pp. 1-93.
[18] E. E. Ananto, Zakiah, and E. Pasandaran, "Potensi lahan rawa pasang surut dalam mendukung peningkatan produksi pangan," J. Litbang Pertan., pp. $153-168$.

[19] M. H. Suwanda and M. Noor, "Kebijakan pemanfaatan lahan rawa pasang surut untuk mendukung kedaulatan pangan nasional," $J$. Sumberd. Lahan, vol. Edisi Khus, pp. 31-40, 2014.

[20] M. S. Imanudin, S. J. Priatna, E. Wildayana, and M. E. Armanto, "Variability of Ground Water Table and Some Soil Chemical Carachteristic on Tertiary Block of Tidal Lowland Agriculture South Sumatera Indonesia,' Sains Tanah, vol. 14, no. 1, pp. 7-17, 2017.

[21] M. Alwi, "Prospek lahan rawa pasang Surut untuk tanaman padi," in Prosiding Seminar Nasional Inovasi Teknologi Pertanian Spesifik Lokasi, 2014, pp. 45-59.

[22] M. Noor, D. Nursyamsi, and A. Fahmi, "Inovasi lahan rawa pasang surut mendukung kedaulatan pangan dan pertanian industrial berkelanjutan berbasis sumberdaya lokal," in Prosiding Seminar Nasional Inovasi Teknologi Pertanian Spesifik Lokasi, 2014, pp. 29-35.

[23] M. Yazid, M. N. Shamsudin, K. A. Rahim, A. Radam, and A. Muda, "The achievement of water management objectives based on willingness to pay for a water service fee in tidal lowlands," Aquat. Ecosyst. Heal. Manag., vol. 16, no. 1, pp. 119-124, 2013. 